http://dx.doi.org/10.12775/szhf.2016.059

\author{
OndRej MarchevskÝ
}

Prešovská univerzita v Prešove, Preszow, SŁowacja

ONDREJ333@GMAIL.COM

\title{
Filozofia i rewolucja. Piotr Tkaczow o roli filozofii w zmienianiu świata*
}

„Зачем нам жить, зачем страдать? Зачем в мучительном томленьи Напрасно истины искать? Зачем решать сомненьи? Оставим их, забудем их!“ Ткачев ВОПРОСЫ

„Я видел: тешился народ. Но странно тешутся рабы! Вокруг жандармов целый взвод,

Кишит полиция внутри!.. И чуть кто крикнет невпопад, Не так шагнет, не так пойдет, Как приказал ходить солдат... Жандарм тут... и бьет, и бьет“ Ткачев НАРОДНОЕ ГУЛЯНЬЕ

Poszukiwanie prawdy, tego co pewne i niewzruszone, ale również zatroskanie o położenie ludu wynikające z przeświadczenia o niedopuszczalnym

Artykuł powstał w ramach grantu VEGA č. 1/0124/16. 
ucisku władzy państwowej to dwie główne myśli zawarte w wierszach Piotra Tkaczowa przywołanych tu jako motto. Wyznaczają one jednocześnie zakres problemów podejmowanych przeze mnie w niniejszym artykule.

Chciałbym tu przede wszystkim postawić pytanie o sens i praktyczną użyteczność filozofii i filozofów w dziele przemian społeczno-dziejowych, $\mathrm{w}$ sposób, w jaki rozumie to zagadnienie jeden $\mathrm{z}$ wybitnych teoretyków rewolucyjnego narodnictwa ${ }^{1}$ Piotr Nikiticz Tkaczow (1844-1882) ${ }^{2}$. Aby odpowiedzieć na to pytanie, skoncentruję się wyłącznie na lekturze tekstów Rosjanina. Podejście ad fontes uważam za najwłaściwszy sposób podjęcia tego zagadnienia, między innymi ze względu na ograniczone rozmiary artykułu. Ale nie tylko dlatego. Jest jeszcze jeden istotny i merytoryczny powód takiego właśnie czysto źródłowego ujęcia. Uważam, że tylko w ten sposób zainteresowany tematem i krytyczny Czytelnik będzie mógł ocenić moje podejście do twórczości filozoficznej Tkaczowa i wykryć możliwe błędy, których trudno czasami się ustrzec. Jestem przekonany, że swobodna wymiana interpretacji i dyskusja nad ich kształtem przynosi pożytek każdemu, kto pragnie zgłębić i zrozumieć jakieś zagadnienie. Pragnąłbym, aby moja praca została potraktowana jako próba włączenia się do takiej dyskusji.

${ }^{1}$ Ros. Narodničestvo. Pojęcie to oznacza najbardziej wpływowy sekularyzacyjny ruch rosyjskiej inteligencji oraz nurt myśli społecznej, politycznej i filozoficznej drugiej połowy XIX wieku. Ruch ten wyraźnie odziaływał na zmiany w społeczeństwie i w polityce Rosji tego okresu. Początki kształtowania się tego ruchu wiążą się z takimi wydarzeniami, jak śmierć cara Mikołaja I (1855), klęska Sewastopola w wojnie krymskiej (1856) czy reforma ustawy pańszczyznianej w Rosji (1861). Problemem do tej pory nierozstrzygniętym jest ustalenie daty końca tego ruchu. W tej kwestii występują poważne różnice stanowisk wśród historyków i historyków filozofii. Jedni uważają, że zakończenie tego ruchu wiąże się z zamachem na cara Aleksandra II (1881), inni łączą z nim upadek Port Arthur (1905) w wojnie rosyjsko-japońskiej, aż po rok 1918, a nawet później (1925). Analizując ten ruch, można odnaleźć kilka wspólnych cech i typowych tematów: troska o naród, poczucie odpowiedzialności za los narodu, moralny dług wobec narodu i powiazane z nim dążenie do jego spłacenia przez inteligencję i działaczy społecznych, dążenie do pracy dla dobra narodu. Widoczne są próby moralnych ocen społeczności tego okresu i tworzenia nowych wartości służących lepszemu życiu narodu i Rosji. Zob. też. np. A. Walicki, Zarys myśli rosyjskiej. Od Oświecenia do renesansu religijno-filozoficznego, Kraków 2005

${ }^{2}$ Ros. Petr Nikitič Tkačev. Z wykształcenia prawnik i świetny znawca systemu sądowego ówczesnej Rosji. Był jednym z najbardziej zradykalizowanych przedstawicieli ruchu narodnickiego, uchodził za ideologicznego wodza radykalnej partii Narodnaja Volia. Prawie całą swoją działalność uważał za przygotowanie do rewolucji w Rosji i wszystkie swoje wysiłki poświecił realizacji tego zadania. Zob. np. V. A. Isakov, Petr Nikitič Tkačev, [w:] P. N. Tkačev, Izbrannoe, Moskva 2010, s. 5-35 
Określając bardziej szczegółowo cel, jaki sobie stawiam, chciałbym skupić się na zagadnieniu przeprowadzenia rewolucji (rozumianej jako nagła i głęboka zmiana społeczna) i roli filozofii w tym procesie. Pierwszym bodźcem do postawienia tego pytania była dla mnie lektura pracy Juridiczeskaja metafizika napisanej przez Tkaczowa w miarę wcześnie, bo już w 1863 roku. To właśnie w tej rozprawie rosyjski myśliciel formułuje swój zasadniczy zamiar, którym jest stworzenie nowej filozofii: „filozofii żywej, owocnej, filozofii prawdziwej, wolnej od wszelkiej metafizyczności, filozofii, która na powrót jednoczy rozdzielone na siłę części nauk społecznych, filozofii, która stanie się nauką socjalną, czyli nauką dla społeczeństwa"3. W swoim wywodzie podkreśla on dalej, że takie przekształcenie jest nieodzowne dla filozofii, która powinna być żywa, prawdziwa i praktyczna. Chodzi tutaj o taką filozofię, która mogłaby stać się podstawą dla przemiany światopoglądów, a poprzez ludzkie działania - również przemiany świata w ogóle. Właśnie taką filozofię autor Metafizyki prawniczej określa mianem realizmu lub też racjonalizmu4.

Równie istotne dla zrozumienia zagadnienia praktycznej użyteczności filozofii $\mathrm{w}$ procesach rewolucyjnych są również idee i pojęcia wypracowane w bogatym intelektualnie i pełnym istotnych wydarzeń okresie nazywanym w historiografii myśli rosyjskiej „latami sześćdziesiątymi” (XIX wieku) ${ }^{5}$. W moim przekonaniu niezwykle istotne i oddające ducha „lat sześćdziesiątych" jest ujęcie, jakie przedstawia sam Tkaczow. Mówiąc bardziej szczegółowo, warto podkreślić dwie ważne tendencje, czy może cechy tego okresu, eksponowane przez rosyjskiego myśliciela. O pierwszej z nich pisze w pracy O pol'ze fitosofii (jest to praca z 1877 roku opublikowana w numerze 5 czasopisma „Dieło", ale znakomicie charakteryzuje poprzednie dziesięciolecie). Teoretyk rewolucyjnego narodnictwa mówi tutaj o ogromnej popularności filozofii i filozofowania w dziewiętnastowiecznej Rosji. Wyróżnia przy tym trzy wielkie obozy, które według niego potwierdzają wspomnianą popularność filozofii. Pierwszy obóz nazywany jest przez Tkaczowa obozem wielkich myślicieli (zalicza do niego na przykład Włodzimierza Sołowjowa (1853-1900), ale też mniej obecnie znanego filologa-slawistę Włodzimierza Łamanskiego

\footnotetext{
${ }^{3}$ P. N. Tkaczow, Juridiczeskaja metafizika, [w:] tenże, Izbrannyje soczynienija, t. 5, Moskwa 1935, s. 29.

${ }^{4}$ Warto na tym miejscu zwrócić uwagę, że pojęcia te nie są w żaden sposób przez Tkaczowa wyjaśniane. Swojemu zamiarowi twórczemu po prostu nadaje on na stronach Metafizyki prawniczej pewne nazwy, podkreślając potrzebę realistycznego, opartego na rozumie i nauce podejścia do zagadnień filozoficznych oraz życiowych.

${ }^{5}$ Zob. np. A. Walicki, Zarys myśli rosyjskiej..., s. 275-278.
} 
(1833-1914)). Drugi obóz nazwany jest przezeń „obozem pozytywistów”, ale mówi też w tym kontekście dość ironicznie o kółkach filozoficznych, czy ściślej klubach „trzeźwych”, „pijanych” czy „tańczących” filozofów ${ }^{6}$. Takim kółkiem był na przykład krąg skupiony wokół związanego z narodnictwem Mikołaja Annienskiego (1843-1912), który prywatnie był kuzynem i szwagrem Tkaczowa, ożenionym z jego siostrą Aleksandrą. Warto też dodać, że w spotkaniach tego kółka często brał udział inny wielki przedstawiciel narodnictwa, Mikołaj Michajłowski. Trzecim obozem, stanowiącym potwierdzenie wielkiej popularności filozofii i filozofowania w Rosji są w przekonaniu Tkaczowa „filozofujący przedstawiciele nauk ścisłych” . W moim przekonaniu bardzo interesująco wyraża atmosferę tych lat następująca myśl Tkaczowa: „Ach, dopiero teraz byłoby klawo! Tyle materiału dla solidnych i poważnych rozmów! Kant, Hegel, Hartmann, Comte, pan P. L. ${ }^{8}$ Michajłowski, Lesiewicz, Kozłow, de Roberti, Kawielin, W. Sołowjow. Ileż zdrowej i pożywnej strawy dla umysłu i serca. I cóż powiecie, czy to nie waga czasów?"”.

Kolejny, niezmiernie ważny motyw dla zrozumienia problemu filozofii i jej stosunku do rewolucji w myśleniu Tkaczowa to sytuacja dziejowo-polityczna, w której, jego zdaniem, znajduje się lud rosyjski. Pewną wskazówką mogą być dla nas myśli wyrażone w wierszach przywoływanych jako motto niniejszego artykułu. Oto rosyjski lud (albo naród, zważywszy na dwuznaczność rosyjskiego słowa narod) staje na rozstaju dróg: albo droga do indywidualności i indywidualizmu, albo droga do wspólnotowości, czyli do swoistego komunizmu. Rosyjski myśliciel i rewolucjonista nie ma wątpliwości, że lud (naród) stanowi ogromną siłę, jest potęgą, ale sama ta moc i potęga nie są w stanie niczego dokonać w sposób żywiołowy i spontaniczny. To jest tylko

${ }^{6}$ P. N. Tkaczow, O pol'ze fiłosofii, [w:] tenże, Kładezi mudrosti rossijskich fiłosofow, Moskwa 1990, s. 225.

7 Tamże, s. 229. Tkaczow, posługując się uwagami rosyjskiego autora A. A. Kozłowa (bez wskazywania źródła tych ocen), wymienia nie Rosjan, lecz obcokrajowców. Odnosi się do Rudolfa Virchowa (1821-1902), Ernsta Heackela (1834-1919) czy Jakoba Moleschotta (1822-1892).

${ }^{8} \mathrm{~W}$ badaniach nad myślą Tkaczowa inicjały P. L. były najczęściej kojarzone z postacią Piotra Ławrowa - trzeciego obok Michajłowskiego i Tkaczowa wybitnego teoretyka narodnictwa rosyjskiego. Jednak moim zdaniem, warto przytoczyć tutaj sugestię B. Szachmatowa, wydawcy współczesnego wyboru pism Tkaczowa, który na podstawie badań korespondencji myśliciela twierdzi, że pod iniciałami tymi kryje się nie Ławrow, lecz Paweł Fiodorovicz Lilienfeld-Toal (1829-1903) - uczony z okresu carskiej Rosji. Zob. przypisy redaktora tomu do wyżej cytowanej pozycji: s. 588 .

9 Tamże, s. 225. 
jakaś wielka potencja, którą trzeba dopiero gdzieś popchnąć. A kiedy mowa jest o tym „popchnięciu”, to w moim przekonaniu Tkaczow ma na myśli rewolucję.

Podkreślę raz jeszcze: moim zdaniem, tym „popchnięciem”, impulsem ożywiającym lud rosyjski jest rewolucja i nic innego. Tak właśnie odczytuję słowa Tkaczowa na temat rewolucji jako wielkiej zmiany społecznej, która jest przede wszystkim szybka (gwałtowna), a co do swych celów całkowicie różni się od wszystkich występujących do tej pory ideałów społecznych. Potwierdzenie tego przekonania można znaleźć w Tkaczowowskiej krytyce genewskiego i brukselskiego kółka socjalistów-anarchistów, zawartej w pracy Anarchiczeskije gosudarstwo ${ }^{10}$. Oskarża on członków tych ugrupowań o to, że nie są w stanie wytworzyć nic nowego, a jedynie dążą do nadania jakiejś nowej formy starym instytucjom, jakimi są państwo i cały jego aparat siłowy. Nie jest to jednak ,inność”, nowość czy odrębność, o którą chodzi myślicielowi. Analogiczną, lecz syntetycznie sformułowaną myśl można odnaleźć także w innym dziele Tkaczowa, w którym krótko stwierdza: „Rewolucją społeczną nazywana jest radykalna przemiana stosunków społecznych i moralnych całego społeczeństwa"11.

W rewolucji chodzi o zmianę doskonale przemyślaną i zaplanowaną, co wyklucza możliwość podważania i negowania celów tej rewolucyjnej przemiany i jej ogólnego pożytku. Używając terminologii rosyjskiego myśliciela, należałoby powiedzieć, że cele te muszą być przede wszystkim „oczywiste” (oczewidnieje). Ażeby uchwycić sens tego przeświadczenia, warto po raz kolejny przywołać słowa Tkaczowa, który następująco pisze o niepodważalnym i jasnym kryterium prawdy:

I takie kryterium istnieje, i nie jest to miraż, ani fantazja. Kryterium tym jest oczywistość, ale nie w tym potocznym znaczeniu tego słowa, w którym często wykorzystywane jest ono w codziennym życiu, oznaczając zwykłe subiektywne przekonanie co do zasadności, tzn. prawdziwości tego czy owego, lecz w tym bardziej ścisłym sensie, zgodnie z którym to, co oczywiste oznacza coś takiego,

\footnotetext{
${ }^{10}$ P. N. Tkaczow, Anarchiczeskoje gosudarstwo, [w:] tenże, Izbrannoje, Moskwa 2010, s. 543-566. Można w tym mięjscu odnotować, że „kółkami“ nazywa Tkaczow dwie frakcje, ugrupowania umysłowe, projekty rewolucyjnej działalności, które zostały przedstawione podczas zjazdu międzynarodówki w Brukseli we wrześniu 1874 roku.

${ }^{11}$ P. N. Tkaczow, Riewolucija i princip nacyonal'nosti, [w:] tenże, Izbrannoje, dz. cyt., s. 651.
} 
co każdy podmiot - niezależnie od tego, jakie są jego osobiste przekonania uznaje za bezwarunkowo przekonujące, czyli prawdziwe ${ }^{12}$.

W ujęciu rosyjskiego myśliciela oczywiste jest coś, z czym mógłby zgodzić się każdy człowiek (indywidualność), zgodzić się bez żadnych wątpliwości, niezależnie od przekonań osobistych, światopoglądu i skłonności politycznych.

Kiedy mowa jest o celach oczywistych, nie sposób nie wspomnieć o centralnym zagadnieniu dla tego dyskursu. Jest to moim zdaniem problem celu zmiany społecznej albo, ujmując rzecz inaczej, ideału postępu. To jest cel, który musi być urzeczywistniony przez rewolucję, ale przed samym urzeczywistnieniem powinien być w sposób oczywisty zdefiniowany. W swoim najgłośniejszym artykule Co to jest partia postępu? (Czto takoje partija progressa?) rosyjski myśliciel uznaje słowo „postęp” za jedno z najbardziej bodaj zwulgaryzowanych pojęć, co wynikać ma $\mathrm{z}$ chronicznej nieokreśloności treści tego pojęcia. Jak sam podkreśla: „Wątpić należy, czy w społecznym użyciu jest więcej takich słów, które byłyby tak często, albo raczej tak nieustannie nadużywane, jak słowo postęp"13.

Tkaczow podkreśla, że pod pojęciem tym rozumiano niemal wszystko albo cokolwiek bądź, a przecież ze względu na siłę oddziaływania tego słowa i jego społeczną funkcję powinno być jasne i oczywiste, co to jest właściwie postęp. Żeby zilustrować pustą treść tego pojęcia rosyjski narodnik przywołuje obraz, który pozwolimy sobie nieco bardziej swobodnie sparafrazować: wyobraźmy sobie, że wszystkie sklepy w mieście, na przykład w Moskwie, Petersburgu albo w Woroneżu, otrzymałyby szyld taki sam szyld, po prostu: „sklep”. Każdy punkt handlowy, niezależnie od oferowanego przez siebie towaru, nazwany byłby tylko „sklep”. I już. W efekcie nie wiedzielibyśmy, co i gdzie kupić. Chcąc rozwiązać tę sytuację, musielibyśmy wchodzić do każdego sklepu, by naocznie sprawdzać jego asortyment. Możemy wprawdzie dokonać przeglądu tych sklepów i ustalić zawarte w nich towary, na przykład w Moskwie. Wyobraźmy sobie jednak, że to samo dotyczy innych miast i że nie mieszkamy tylko w Moskwie. Próba zrobienia zwykłych zakupów, na przykład żywności, przyprawiałaby o szaleństwo. Pojęcie „sklep”, tak jak pojęcie „postęp”, traci wszelkie znaczenie, bo obejmuje wszystko, dotyczy wszystkiego. Według Tkaczowa ma to fatalne konsekwencje. W podanym

\footnotetext{
${ }^{12}$ P. N. Tkaczow, Czto takoje partija progressa?, [w:] tenże, Izbrannoje, dz. cyt., s. 285

${ }^{13}$ Tamże, s. 277.
} 
wyżej przykładzie sklepów o jednakowych szyldach tracimy czas i grozi nam ból nóg oraz zniszczenie obuwia. W przypadku pojęć społecznych wkraczamy jednak na płaszczyznę działań politycznych, gdzie skutki o tyle mogą okazać się fatalne, o ile niejasność i niezgoda doprowadzić może do rozlewu krwi w walkach wewnętrznych pomiędzy nierozumiejącymi się nawzajem stronnictwami postępowców. Nie można jednak do tego dopuścić. Pojęcie „postępu” musi być oczywiste i pewne, bo jest ono podstawą wszelkich działań rewolucyjnych ${ }^{14}$.

Moje dotychczasowe rozważania doprowadziły mnie do dwóch bardzo ważnych pytań. Pierwsze pytanie dotyczy tego, jaka jest oczywista treść pojęcia postępu? W twórczości Tkaczowa jest to problem wielowątkowy i zasługujący na odrębne, obszerne rozważenie ${ }^{15}$. Dla ilustracji pozwolę sobie jednak przytoczyć pewne sformułowanie sensu idei postępu u tego rosyjskiego myśliciela:

I tak, ustanowienie możliwie najpełniejszej równości poszczególnych jednostek (równość ta nie powinna być mieszana $\mathrm{z}$ równością polityczną i prawną, ani nawet ekonomiczną - jest to równość organiczna, fizjologiczna, warunkowana jednością wychowania i wspólnotą warunków życia) i doprowadzenie potrzeb wszystkich ludzi i każdego z osobna do stanu pełnej harmonii ze środkami potrzeb tych zaspokajania - taki jest konieczny, jedyny możliwy cel społeczności ludzkiej, takie jest najwyższe kryterium postępu historyczno-społecznego. Wszystko, co przybliża społeczeństwo do tego celu - jest postępowe; wszystko, co oddala - jest regresywne ${ }^{16}$.

Druga kwestia, na której chciałbym się tutaj skupić, jest problemem $\mathrm{w}$ gruncie rzeczy politycznym, wyrażanym w pytaniu o to, kto właściwie powinien definiować to, czym jest postęp, a więc określać kierunek i cel przemian społecznych?

Szukając odpowiedzi na tak postawione pytanie („,kto jest zdolny zdefiniować postęp w sposób oczywisty?”), znajdujemy u Tkaczowa najpierw odpowiedź negatywną. Tkaczów mówi o tym, kto zdecydowanie tego nie powinien czynić. W żadnym razie nie może zabierać się za to rewolucjonista. Sugestię, mówiącą, że praca dla rewolucji wyklucza pracę na rzecz definiowania po-

\footnotetext{
14 Tamże, s. 278-279.

${ }^{15}$ Niektóre wątki tego zagadnienia podjąłem w mojej rozprawie doktorskiej: Filozofická reflexia dejín v dielach predstavitelov jadra ruského národníctva, Presov 2013.

16 Tenże, Czto takoje partija progressa?, dz. cyt., s. 322.
} 
jęcia postępu, możemy odnaleźć w programowym artykule pisma „Nabat”, w którym znaleźć można takie oto słowa:

Przygotowanie rewolucji - nie jest bynajmniej sprawą rewolucjonisty. Przygotowują ją wyzyskiwacze - kapitaliści, ziemianie, popi, policja, urzędnicy, konserwatyści, liberałowie, postępowcy itp. Rewolucjonista natomiast powinien tylko wykorzystywać i w odpowiedni sposób połączyć gotowe, dane już elementy rewolucyjne, które wypracowała historia, które stworzyło życie gospodarcze ludu, które umacniają się i rozwijają dzięki tępocie »zachowawców«, głupocie rządów wraz z ich żandarmami i wojskami - dzięki, wreszcie, pracowitym budowniczym mirażu światowego postępu i ich burżuazyjnej nauce. Rewolucjonista nie przygotowuje rewolucji, lecz jej dokonuje. Róbcie ją zatem! Róbcie szybciej. Wszelkie niezdecydowanie, każda zwłoka - to zbrodnia. Alarm! Alarm! ${ }^{17}$.

Jak można zauważyć, przytoczona przeze mnie myśl Tkaczowa nie ma jedynie sensu negatywnego $\mathrm{w}$ stosunku do zadanego przeze mnie pytania. Pokazuje nawet kilka typów ludzkich lub grup, instytucji społecznych albo państwowych, które swoją działalnością przygotowują rewolucję i jako takie określają treść pojęcia postępu. Nie sądzę jednak, żeby była to wyczerpująca odpowiedź na pytanie, które jest dla mnie w tej pracy kluczowe. Przywołane przez ideologa rosyjskiej rewolucji przykłady można traktować jako pewne bodźce lub pobudki do działania. Ostatecznie jednak nie można ich uważać za jedyne i wiarygodne źródła w poszukiwaniu określenia tego, czym postęp jest, w jakim kierunku i do jakich celów powinna zmierzać rewolucja. Działalność tych czynników można odczytywać, jako pewną motywację, pobudkę dla zmiany dokonywanej przez rewolucję i prawdziwych rewolucjonistów. Tkaczow podkreśla w tym artykule, że rewolucjonista „jedynie” dokonuje rewolucji, urzeczywistnia pewne cele i ideały w swoim działaniu praktycznym. Natomiast myślenie o samych celach i ich zasadności nie jest jego zadaniem.

A zatem, skoro nie rewolucjonista, to może filozof jest postacią odpowiednią do zdefiniowania tego, czym jest postęp. Mogłoby to potwierdzać na przykład deklarowane przez Tkaczowa dążenie do zreformowania filozofii i jego przekonanie o spontanicznej skłonności największych umysłów do filozofii i filozofowania. Czy zatem to właśnie filozof nie powinien określić oczywistej treści pojęcia postępu? Trzeba podkreślić, że nie jest to kwestia tylko pewnych wskazówek, bo Tkaczow pisze zarazem: „Weźmy jakikolwiek

${ }^{17}$ P. N. Tkaczow, Nabat (programma żurnała), [w:] tenże, Izbrannoje, dz. cyt., s. 455. 
system filozoficzny - każdy z nich ma jedną wspólną, charakterystyczną cechę: każdy próbuje ująć wielość poznawalnych zjawisk w jeden ogólny obraz i podporządkować je władztwu jednej fundamentalnej zasady czy reguły"18. Ale to nie wszystko. Tkaczow na tym nie poprzestaje, i w taki sposób ocenia ten stan rzeczy: „Jednak do tej pory, ani jedna z tych prób nie dała jakichkolwiek zadowalających rezultatów" ${ }^{\prime 19}$. Rosyjski myśliciel, żeby uzasadnić swoją pesymistyczną ocenę w innym miejscu tej samej pracy stwierdza:

Dążenie ludzkiego umysłu do abstrakcyjnych uogólnień konkretnych zjawisk, kiedy zamknąć je w pewnych granicach, przynosi ludzkości niewątpliwą korzyść. Ale przekraczając te granice, czyż nie staje w opozycji do innego dążenia - dążenia do poznania rzeczywistej prawdy [rieal'noj istiny]? Oto pytanie, które obrońcy filozofii powinni byliby zadawać sobie częściej, ale które zazwyczaj ignorują. Stopnie abstrakcji są nieskończone, dokąd możemy po nich się wznosić, nie czyniąc szkody rzeczywistej prawdzie? Czyż nie powinniśmy się zatrzymać zanim nie dotrzemy do tego górnego poziomu, na którym usadowiła się filozofia? ${ }^{20}$.

Czytając zatem rozprawę Tkaczowa na temat pożytków z filozofii, dowiadujemy się niestety, że nawet filozofia nie jest w stanie określić treści pojęcia postępu, chociaż być może posiada jakieś walory społeczne. Takimi walorami są praca umysłowa zanurzająca się w głębiach życia, zdolność filozofii do ukazywania ludzkich problemów w szerszym kontekście oraz pluralizm poglądów, tak charakterystyczny dla filozofii, który - zdaniem Tkaczowa - działa jak balsam dla duszy. Ale walorem bodaj największym jest zdolność pokonywania wszystkich -izmów. Bo jak pisze rosyjski myśliciel: „Kultura filozoficzna jest dla społeczeństwa najważniejszą barierą dla wszelkich -izmów”21.

Paradoksalnie właśnie to chyba najbardziej dyskwalifikuje filozofię w oczach Tkaczowa, przynajmniej jeśli chodzi o jej zdolność do określania treści pojęcia postępu. Bo to, do czego zamierza Tkaczow, to jest właśnie -izm. Filozofia z punktu widzenia Tkaczowa, to coś w rodzaju rozmowy, która jest zajmująca, może nas zaciekawić, zachwycać, ale jest nieużyteczna i po-

\footnotetext{
18 Tenże, O pol'ze fiłosofii, dz. cyt., s. 239.

19 Tamże, s. 239.

20 Tamże, s. 241

21 Tamże, s. 255.
} 
zbawiona praktycznego sensu. A nawet często odciąga nas od podjęcia prawdziwych problemów, zmierzenia się z nimi od razu w samej ich aktualności ${ }^{22}$.

A zatem pytanie zadane wcześniej: kto definiuje postęp, nadal pozostaje otwarte. Może więc historyk i historia? Tkaczow bardzo często odnosi się do pracy historyka i wiedzy historycznej jako takiej. Świadomie powstrzymuję się od obszerniejszego skomentowania tego wątku, bo chciałbym się nim zająć w dalszej części pracy. Rosyjski myśliciel pisze: „Zadanie historyka polega na tym, żeby zbadać i uchwycić konieczny związek i wewnętrzną logikę faktów historycznych, następowanie i współwystępowanie wytwarzanych przez historię stanów społecznych"23. To zarys tego, jak według Tkaczowa powinien pracować rzetelny historyk. Dostrzegam tutaj jeden bardzo ważny problem. Historyk i historiografia byłyby może do tego zdolne, ale pod warunkiem osiągnięcia wiedzy o tym, co jest oczywiste. Bo bez tej wiedzy, pisze w innym miejscu Rosjanin: „Historia jest zwykłą dziewczyną uliczną, która daje każdemu wszystko, czego kto od niej zapragnie. Przy jej pomocy można udowodnić każde stanowisko, chociaż są do tego potrzebne, po pierwsze, pewna zręczność, a pod drugie, jakaś wiedza"24. Podobną ocenę można odnaleźć w jeszcze jednym fragmencie. Tkaczow pisze na temat historiografii następująco: „Trudno wyobrazić sobie inną gałąź ludzkiej wiedzy, która znajdowałaby się w bardziej opłakanym, chaotycznym położeniu niż ona. Ktoś, nie bez podstaw, porównał ją z kobietą lekkich obyczajów, z której usług korzysta każdy jak tylko chce. $\mathrm{W}$ historii, jak $\mathrm{w}$ wielkim muzeum, bez trudu można znaleźć oręż do walki z kim się chce i z czym się chce"25. W jeszcze innej pracy można znaleźć dopełnienie tych ocen: „Historia jest w pewnym sensie matką wszystkich potrzebujących. Zwracają się do niej konserwatyści i demokraci, rojaliści i republikanie, socjaliści i bonapratyści - każdego pociesza i podnosi na duchu, każdemu daje coś dla obrony jego doktryny i dla

\footnotetext{
${ }^{22}$ Humorystycznie na tę bezsensowność czy też niepraktyczność filozofii wskazuje Tkaczow w krótkim opowiadaniu o swoim przyjacielu, który choć zaproszony na obiad, nie dostał go wcale, bo zapraszająca rodzina posiłek już zjadła i zapomniała o nieszczęsnym gościu. Ten zaś, głodny, lecz taktowny, zamiast wprost zapytać o jedzenie dla siebie, starał się ich naprowadzić na to długimi rozważaniami o higienie i potrzebie regularnego odżywiania się. Niestety jego krasomówstwo pozostało bez odpowiedzi. Tamże, s. 231-233.

${ }^{23}$ P. N. Tkaczow, Rol' mysli w istorii, [w:] tenże, Kładezi mudrosti rossijskich fiłosofow, dz. cyt., s. 155

${ }^{24}$ P. N. Tkaczow, Utilitarnyj princip nrawstwiennoj fiłosofii, [w:] tenże, Kładezi mudrosti rossijskich fiłosofow, dz. cyt., s. 369.

${ }^{25}$ Tenże, Rol' mysli $w$ istorii, dz. cyt., s. 152-153.
} 
pognębienia antagonistów"26. Wynika stąd, że historyk nie jest w stanie autorytatywnie określić, czym jest postęp, jest on jedynie zdolny dzięki jakiejś wiedzy szczegółowej ocenić całą historię i jej okresy jako progresywne lub regresywne.

Należy zatem rozważyć kolejną możliwość. Może więc to pisarz bądź dziennikarz są zdolni do tego, by kompetentnie określić, na czym polega postęp. To właśnie zdaje się sugerować pierwszy artykuł zawarty w pracy Anarchija mysli, opublikowany w czasopiśmie „Nabat”. Tkaczow zajmuje się w nim analizą zagranicznej, rosyjskiej prasy rewolucyjnej wydawanej przez kręgi emigracyjne. Taka analiza wydaje się dla niego bardzo ważna, bo jak pisze, w wydawnictwach tych „rozjaśnia się młodzieży jej rewolucyjne ideały, udziela się jej rad i przekazuje wskazówki dotyczące praktyki rewolucyjnej, w których tak czy inaczej rozstrzygane są główne problemy jej działalności”27.

$\mathrm{W}$ związku z tym nasuwają mi się pewne podejrzenia, że istnieje pewien związek pomiędzy problemami historiografii i pracy historyka oraz niektórymi problemami wyraźnie dostrzeganymi na gruncie filozofii. Prasa tak samo jak nauki historyczne, a dziennikarz tak samo jak historyk, są - w moim odczytaniu myśli Tkaczowa - tylko pewnym środkiem wyrazu służącym ukazaniu tego, co jest postępowe w aktualnym dziennikarstwie i tego co było postępowe w przeszłości. Historyk i dziennikarz, ale także pisarz, pokazują co i jak powinni dokonać w rewolucji rewolucjoniści i gdzie w dziejach szukać do tego inspiracji. Rodzi się jednak obawa, że nie wszyscy dziennikarze lub pisarze, tak samo jak nie wszyscy filozofowie, wiedzą, co jest tym celem oczywistym, który tak ważny jest dla samego Tkaczowa. Dziennikarstwo niewiele różni się pod tym względem od filozofii, stwarza jedynie warunki dla dyskusji i prezentacji różnych poglądów, a nie dostarcza podstaw do formułowania ostatecznych, „oczywistych” celów. Filozofia prezentuje wielość stanowisk, wartości i celów, historia z kolei jest dziedziną, w obrębie której dokonuje się jedynie selekcji faktów pasujących do wyznawanej ideologii. Dziennikarstwo zaś sytuowałoby się jak gdyby pomiędzy nimi. Natomiast Tkaczow zamierza wyjść poza bezpłodną, jego zdaniem, dyskusję, by zyskać świadomość tego, co być musi, bo inaczej być nie może.

W podsumowaniu chciałbym zaproponować pewną hipotezę. Składają się na nią dwa punkty. Po pierwsze być może udało mi się wskazać tu jeden

${ }^{26}$ P. N. Tkaczow, Francuzkoje obszczestwo $w$ konce XVIII wieka, [w:] tenże, Soczynienija w 2-ch tomach, t. II, Moskwa 1976, s. 154.

${ }^{27}$ P. N. Tkaczow, Anarchija mysli, [w:] Kładezi mudrosti rossijskich fiłosofow, dz. cyt., s. 177. 
z wątków, których Tkaczow nie zdążył już rozwinąć w taki sposób, w jaki opracował tematy zawarte $w$ innych swoich pracach, takich jak na przykład Pedagogika - rodnaja doczka psichołogii albo Izdatielskaja i literaturnaja dejatelnost' Błagoswietłowa. W rozprawach tych wskazuje jedynie pewne idee, do których zamierzał powrócić w kolejnych swoich szkicach, ale ostatecznie tematów tych nie kontynuował, a przynajmniej w pracach, które zachowały się dla potomności wątków tych już nie znajdujemy. Być może więc odpowiedź została udzielona w rozprawach, które zaginęły, jak na przykład Esteticzeskaja kritika na poczwie nauki. Po drugie być może ostatecznie to sam Piotr Tkaczow, i tylko on, niczym wybraniec, miał być zdolny, by zdecydować o tym, czym jest postęp. Do tego rozwiązania sam najbardziej się skłaniam.

Jeśli przyjmiemy tę myśl i jednocześnie powrócimy do zamiaru Tkaczowa zreformowania filozofii czy nawet mocniej: do stworzenia nowej filozofii, to wówczas trzeba zastanowić się nad tym, czym byłaby taka filozofia i kim miałby być filozof. Odpowiedź, jaka nasuwa się w tym przypadku, chociaż zdaję sobie sprawę ze wszystkich jej słabości, zmierzałaby do utożsamienia filozofii z ideologią, a filozofa z ideologiem. Tylko taka, "zideologizowana” filozofia się byłaby zdolna do przeprowadzenia rewolucji.

Czytelnik mojego artykułu zapewne może poczuć pewien niedosyt, a nawet uznać za niestosowne pozostawienie pracy bez rozstrzygającej konkluzji. Zaproponowanie jedynie pewnej hipotezy, co do której sam autor ma niejakie wątpliwości, wydaje się niewystarczające i pozostawia uczucie pewnego niedosytu. Jednak mój przyczynek był tylko próbą podzielenia się z życzliwym Czytelnikiem tym, do czego doprowadziły mnie badania nad myślą rosyjskiego narodnictwa i dziedzictwem intelektualnym Tkaczowa. Jest to więc raczej zachęta do dyskusji, prośba o korektę błędów, których być może nie uniknąłem, albo wskazanie mi nowych sposobów ujęcia tego zagadnienia.

\section{Bibliografia}

Isakov, V. A., Petr Nikitič Tkačev, [w:] Tkačev, P. N., Izbrannoe, ROSSPÈN Moskva 2010, s. 5-35.

Isakov, V. A., Koncepciâ zagovora v radikal noj socialističeskoj oppozicii. Vtoraâ polovina 1840-h - pervâa polovina 1880-h godov, Izdatel'stvo OOO Frantèra, Moskva 2004. 
Šahmatov B. M., Petr Nikitič Tkačev, [w:] Tkačev P. N., Kladezi mudrostirossijskih filosofov. Iz istorii otečestvennoj filosofskoj mysli. Pravda, Moskva 1990, s. 3-8.

Šahmatov B. M., Primečaniâ, [w:] Tkačev P. N., Kladezi mudrosti rossijskihfilosofov. Iz istorii otečestvennoj filosofskoj mysli, Pravda, Moskva 1990, s. 577-608.

Tkačev P. N., Čto takoe partiâ progressa?, [w:] tenże, Izbrannoe, ROSSPÈN, Moskva 2010, s. 277-341.

Tkačev P. N., Nabat (Programma žurnala), [w:] tenże, Izbrannoe, ROSSPÈN, Moskva 2010, s. 453-466.

Tkačev P. N., Anarhičeskoe gosudarstvo, [w:] tenże, Izbrannoe, ROSSPÈN, Moskva 2010, s. 543-566.

Tkačev P. N., Revolûciâ i princip nacional'nosti, [w:] tenże, Izbrannoe, ROSSPÈN, Moskva 2010, s. 642-662.

Tkačev P. N., Rol' mysli v istorii, [w:] tenże, Kladezi mudrosti rossijskihfilosofov. Iz istorii otečestvennoj filosofskoj mysli, Pravda, Moskva 1990, s. 128-174.

Tkačev P. N., Anarhiâ mysli, [w:] tenże, Kladezi mudrosti rossijskih filosofov. Iz istorii otečestvennoj filosofskoj mysli, Pravda, Moskva 1990, s. 175-195.

Tkačev P. N., Pedagogika - rodnaâ dočka psihologii, [w:] tenże, Kladezi mudrosti rossijskih filosofov. Iz istorii otečestvennoj filosofskoj mysli, Pravda, Moskva 1990, s. 196-222.

Tkačev P. N., O pol'ze filosofii, [w:] tenże, Kladezi mudrosti rossijskih filosofov. Iz istorii otečestvennoj filosofskoj mysli, Pravda, Moskva 1990, s. 223-255.

Tkačev P. N., Utilitarnyj princip nravstvennoj filosofii, [w:] tenże, Kladezi mudrosti rossijskih filosofov. Iz istorii otečestvennoj filosofskoj mysli, Pravda, Moskva 1990, s. 359-392.

Tkačev P. N., Izdatel'skaâ i literaturnaâ deâtel'nost' G. E. Blagosvetlova, [w:] tenże, Kladezi mudrosti rossijskih filosofov. Iz istorii otečestvennoj filosofskoj mysli, Pravda, Moskva 1990, s. 550-576.

Tkačev, P. N., Francuzskoe obŝestvo v konce XVIII veka, [w:] tenże, Sočineniâv 2-h Tomah, t. 2, Izdatel'stvo Mysl', Moskva 1976, s. 154-162.

Tkačev P. N., Uridičeskaâ metafizika, [w:] tenże, Izbrannye sočineniâ, t. 5, Moskva 1935, s. 29.

Walicki A., Zarys myśli rosyjskiej. Od Oświecenia do renesansu religijno-filozoficznego, Wydawnictwo Uniwersytetu Jagiellońskiego, Kraków 2005. 


\section{Abstract \\ Philosophy and Revolution. Piotr Tkaczow on the Role of Philosophy in Changing of the World}

In the following paper, the meaning of philosophy as a specific intellectual activity would be presented on the example of revolutionary thoughts of Peter Tkachov. The paper concerns with the understanding of philosophy, its characteristics and status within the Russian intellectual movement in the second half of the 19th century. The understanding of both, individual and social functions of philosophy in the work of Tkachov revolutionary writing, is introduced. The paper is set within a wider framework of Thachov thoughts and his idea of progress. After connecting these two specific topics of Tkachov, the question is formulated: Who is capable to answer the question of what is progress? While looking for an answer and studying works of Tkachov, a wide spectrum of possible variations is offered. The work is purposely conceptualized with an opened closure to present a concrete problem for further analysis and discussion.

Key words: Russian philosophy, history, revolution, progress, ideology, P. N. Tkachov 